OPEN ACCESS

Edited by:

Guochang $\mathrm{Hu}$,

University of Illinois at Chicago,

United States

Reviewed by:

Wenming Zhang,

Stanford University, United States

Johanna Smeekens,

University of North Carolina at

Chapel Hill, United States

*Correspondence:

Annette Kuehn

annette.kuehn@lih.lu

Specialty section:

This article was submitted to

Inflammation,

a section of the journal

Frontiers in Immunology

Received: 13 August 2020 Accepted: 11 December 2020

Published: 28 January 2021

Citation:

Czolk R, Klueber J, Sørensen M,

Wilmes $P$, Codreanu-Morel $F$,

Skov PS, Hilger C, Bindslev-Jensen C,

Ollert M and Kuehn A (2021) lgEMediated Peanut Allergy: Current and

Novel Predictive Biomarkers for

Clinical Phenotypes Using

Multi-Omics Approaches.

Front. Immunol. 11:594350.

doi: 10.3389/fimmu.2020.594350

\section{IgE-Mediated Peanut Allergy: Current and Novel Predictive Biomarkers for Clinical Phenotypes Using Multi-Omics Approaches}

\author{
Rebecca Czolk ${ }^{1,2}$, Julia Klueber ${ }^{1,3}$, Martin Sørensen ${ }^{4,5}$, Paul Wilmes ${ }^{6}$, \\ Françoise Codreanu-Morel ${ }^{7}$, Per Stahl Skov ${ }^{3,8,9}$, Christiane Hilger ${ }^{1}$, \\ Carsten Bindslev-Jensen ${ }^{3}$, Markus Ollert ${ }^{1,3}$ and Annette Kuehn ${ }^{1 *}$ \\ 1 Department of Infection and Immunity, Luxembourg Institute of Health, Esch-sur-Alzette, Luxembourg, 2 Faculty of Science, \\ Technology and Medicine, University of Luxembourg, Esch-sur-Alzette, Luxembourg, ${ }^{3}$ Department of Dermatology and \\ Allergy Center, Odense Research Center for Anaphylaxis, University of Southern Denmark, Odense, Denmark, ${ }^{4}$ Department \\ of Pediatric and Adolescent Medicine, University Hospital of North Norway, Tromsø, Norway, ${ }^{5}$ Pediatric Research Group, \\ Department of Clinical Medicine, Faculty of Health Sciences, UiT The Arctic University of Norway, Tromsø, Norway, \\ ${ }^{6}$ Luxembourg Centre for Systems Biomedicine, University of Luxembourg, Esch-sur-Alzette, Luxembourg, ${ }^{7}$ Department of \\ Allergology and Immunology, Centre Hospitalier de Luxembourg-Kanner Klinik, Luxembourg, Luxembourg, ${ }^{8}$ RefLab ApS, \\ Copenhagen, Denmark, 9 Institute of Immunology, National University of Copenhagen, Copenhagen, Denmark
}

Food allergy is a collective term for several immune-mediated responses to food. IgEmediated food allergy is the best-known subtype. The patients present with a marked diversity of clinical profiles including symptomatic manifestations, threshold reactivity and reaction kinetics. In-vitro predictors of these clinical phenotypes are evasive and considered as knowledge gaps in food allergy diagnosis and risk management. Peanut allergy is a relevant disease model where pioneer discoveries were made in diagnosis, immunotherapy and prevention. This review provides an overview on the immune basis for phenotype variations in peanut-allergic individuals, in the light of future patient stratification along emerging omic-areas. Beyond specific IgE-signatures and basophil reactivity profiles with established correlation to clinical outcome, allergenomics, mass spectrometric resolution of peripheral allergen tracing, might be a fundamental approach to understand disease pathophysiology underlying biomarker discovery. Deep immune phenotyping is thought to reveal differential cell responses but also, gene expression and gene methylation profiles (eg, peanut severity genes) are promising areas for biomarker research. Finally, the study of microbiome-host interactions with a focus on the immune system modulation might hold the key to understand tissue-specific responses and symptoms. The immune mechanism underlying acute food-allergic 
events remains elusive until today. Deciphering this immunological response shall enable to identify novel biomarker for stratification of patients into reaction endotypes. The availability of powerful multi-omics technologies, together with integrated data analysis, network-based approaches and unbiased machine learning holds out the prospect of providing clinically useful biomarkers or biomarker signatures being predictive for reaction phenotypes.

Keywords: endotypes, food allergy, peanut allergy, phenotypes, predictive biomarker

\section{TYPE-I HYPERSENSITIVITY TO FOOD}

Food allergies (FA) are considered as an important public health concern $(1,2)$. FA can be classified into IgE-mediated, non-IgEmediated and mixed types (3). This review focuses on IgEmediated food allergy which is the best-known type among those food-adverse events.

\section{Epidemiology}

There is a general perception that FA prevalence increased during the last twenty years. FA prevalence has been estimated up to $8 \%$ in the pediatric and $11 \%$ in the adult population based on a number of surveys $(2,4,5)$. Beyond the sheer patient numbers, FA entails an important socioeconomic impact, causing fear of accidental exposure in patients and their families, reduced quality of life and relevant healthcare costs nearly double the amount compared to non-allergic individuals $(6,7)$.

\section{Pathophysiological Basis}

IgE-mediated FA is considered as an epithelial barrier disease, resulting from food protein uptake via disrupted barriers (gastrointestinal tract, skin, lung) which in turn, leads to an immune dysregulation, and finally, food proteins being recognized as hostile invaders in a $\mathrm{T}$ helper type 2 (Th2)skewed immune response $(3,8)$. During sensitization, epithelium-derived danger signals and pro-inflammatory cytokines, including interleukin 25 (IL-25) and IL-33, orchestrate the activation and expansion of type 2 innate lymphoid cells (ILC2) and dendritic cells (DCs) (9-11). Those activated DCs promote again the differentiation of naive $\mathrm{T}$ cells into a Th2 phenotype cells. Th2 cells and ILC2 foster the recruitment of basophils and eosinophils into the tissue beneath the epithelium (mucosa, lamina propria) through the secretion of pro-inflammatory cytokines (eg, IL-4, IL-5, IL-13) (3). Th9 cells, another effector T helper subset maturating under the influence of IL-4 and transforming growth factor beta (TGF$\beta$ ), release IL-9, a cytokine which promotes the tissue accumulation of mast cells. B cell class switching to plasma cells producing food antigen-specific IgE is also fostered through IL-4 secretion by Th2 cells. Specific IgE-antibodies bind to the high-affinity IgE receptor (FcERI) on effector cells, basophil granulocytes and mast cells (11-14). In the elicitation phase, food antigens undergo molecular interactions with cell-bound IgE-antibodies via specific epitopes, leading to cell activation and mediator release via crosslinking of FceRI-bound IgE.
Subsequently released inflammatory mediators, including histamine, prostaglandins, tryptase, and platelet-activating factor (PAF), contribute to the clinical symptoms.

\section{Clinical Features}

Food-allergic patients present with a marked diversity by reactivity profiles (15). Clinical symptoms range from mild to severe (severity score) as does eliciting doses (sensitivity score) and time to reaction onset are highly variable $(16,17)$. The estimated dose likely to trigger reactions in $10 \%$ of a study population $\left(\mathrm{ED}_{10}\right)$ vary also for specific foods (eg, peanut $11 \mathrm{mg}$; shrimp $12.8 \mathrm{~g}$ protein) (18). The organ involvement may relate to the skin and/or gastrointestinal tract, but also respiratory/ cardiovascular symptoms in the case of potentially lifethreatening anaphylaxis. Although most patients suffer from stereotypic symptoms, threshold doses depend on multiple factors under real-life conditions (atopic comorbidities; cofactors eg, exercise, alcohol, nonsteroidal anti-inflammatory drugs) (19-21). Disease prognosis and progression may also vary depending on the food allergy, such as in milk or egg allergy, which is commonly outgrown, compared to peanut allergy, which often persists lifelong (22).

\section{Food Allergens}

A large variety of foods can cause allergic reactions and constantly, new allergenic foods are reported (23-25). The most allergenic foods include plant (peanuts, tree nuts, wheat, soy) and animal sources (milk, eggs, fish, shellfish) (13). Food allergens, the molecular drivers of allergen-specific Th2-immune responses, share molecular properties and belong to few structural protein superfamilies (26). Commonly, food allergens involved in food anaphylaxis exhibit a higher stability from digestion/processing as compared to low-allergenic homologs (27-29). Intrinsic characteristics contributing to Th2-immune modulation, such as the house dust mite allergen Der $\mathrm{p} 2$ acting with auto-adjuvant properties via Toll-like receptor (TLR)4 signaling, are less known for food allergens (30). In-vitro models suggest that matrix effects might contribute to facilitate cross-barrier allergen uptake (eg, peanut lipids inhibiting immune-suppressive IL-10) (31). Class I food allergens are primary food allergens (eg, peanut Ara h 2). The "pollen-fruit syndrome" is mediated by specific IgE to pathogenesis-related protein-10 (PR-10; eg, birch Bet v 1) and/ or profilins (eg, birch Bet v 2) as well as antibody crossrecognition of homolog class II food allergens (eg, PR-10: peanut Ara $h$ 8). Those patients experience usually mild FA symptoms (32). 


\section{Food Allergy Diagnosis}

Usually a detailed anamnesis and IgE-tests are combined (33). In single cases, oral food challenges (OFC) are necessary, timeconsuming procedures entailing a significant health risk (34). IgE (skin prick test, SPT; serum specific $\operatorname{IgE} / \mathrm{sIgE}$ ) is an important biomarker. Though, there is a clear trend to overdiagnosing FA as specificity of the testing is low at diagnostic cut-offs (skin wheal size diameter $3 \mathrm{~mm}$, serum $\operatorname{sigE} 0.1 \mathrm{kU}_{\mathrm{A}} / \mathrm{L}$ ). Combining medical data, SPT and sIgE (extract, component-resolved sIgE) increase the diagnosis performance and might approximate OFC outcome $(26,35-37)$. There is the general notion that multiple IgE epitope recognition patterns correlate to FA severity and unfavorable disease progression $(38,39)$. Other serological parameters (e.g., total IgE, food-specific IgG4, sIgE/IgG4) are reported as discordant data. Functional assays using living cells, basophils (blood-/cell line-based) or mast cells (cell lines) feature an important added value in FA-diagnosis, although not yet being implemented into routine (29). Serum mediator levels, including histamine, tryptase and prostaglandin D2 metabolite levels, provided less consistent data like in venom- and druginduced anaphylaxis (40). Overall, usable, reliable and affordable in-vitro predictors of clinical presentation (eg, severity, sensitivity) and risk stratification are evasive and considered still as important knowledge gaps (41). Such predictors may vary depending on the eliciting food, and therefore need to be evaluated for each food allergy.

\section{EMERGING OMIC-AREAS FOR CLINICAL ENDOTYPING}

Peanut allergy (PA) is the focus of many research studies, due to its high prevalence, spectrum of clinical phenotypes, severity and lifelong duration, therefore it will be used as an example throughout. Here, we will give an overview of the immune basis for phenotype variations. We span from non-omics to omicareas, with a focus on studies using cutting edge-technologies and studies based on patient reactivity stratification. A complete overview on biomarker approaches in peanut allergy can be found in Table 1.

\section{Molecular Endotyping}

The deep analysis of allergens by proteomic technologies (allergenomics), based on mass spectrometry (MS), pushed the boarders of knowledge around allergenic peanut proteins including basic aspects of primary structures and posttranslational modifications (95-97).

\section{Non-Omics}

A total of 18 unique peanut iso/allergen are reported (with Ara h 4 now being considered an isoallergen of Ara h 3) (98). Serum IgEreactivity to seed storage proteins, including $2 \mathrm{~S}$ albumins (Ara h 2, Ara h 6) and cupins (Ara h 1, Ara h 3) relates to primary PA. Cross-reactivity markers are the PR-10 protein Ara h 8 (birch allergy) and the non-specific lipid transfer proteins (nsLTP) Ara $h$ 9 (peach-related fruit allergy). The diagnostic relevance of molecular vs extract-based IgE-signatures seems to vary for patient groups from different geographic origins (42, 99-101). However, a recent meta-analysis summarized the overall high diagnostic accuracy of sIgE to Ara h 2 in terms of sensitivity and specificity (95\% CI 75.6, 88.9 and 95\% CI 77.4, 88.4, respectively) at a cut-off of $0.35 \mathrm{kU}_{\mathrm{A}} / \mathrm{L}$ (37). Patients are often IgE-positive for both Ara h 2 and Ara h 6. Recently, Ara h 2 was described as the immunodominant molecule among the two allergens, with higher capacity to activate in-vitro effector cells (basophils, mast cells), pointing to a greater role of Ara h 2 in both disease pathophysiology and as diagnostic severity marker (Figure 1) (43). Even allergen peptides can be beneficial. Indeed, systematic peptide-based scanning approaches (epitope mapping) revealed that increasing IgE-epitope diversity correlated with a more severe phenotype $(38,67)$. In-vitro basophil activation tests (BAT), using basophils from peanut-allergic patients challenged with peanut protein, revealed dose-dependent activation (\%-CD63+ basophils). High performance to identify clinical PA (98.7\% specificity, $74.7 \%$ sensitivity) and high precision to identify individuals with severe outcome (97\% specificity, 100\% sensitivity) has been recently reported for large UK study populations (Table 1) (65). Here, the best prediction of low threshold reactivity was determined in a multivariate statistical tool combining various parameters, SPT, sIgE (Ara h 2, peanut extract), peanut extract-sIgG4/IgE quotient and BAT. In a similar integrated approach, a predictive algorithm based on the CD63 ratio (BAT with peanut protein) and clinical parameters (eg, exercise-induced asthma), had been proposed to predict severe reactions (66).

\section{Allergenomics}

As an extension to allergenomics as an analysis of the allergen repertoire of an allergen source, a new research axis applied proteomic approaches to study in-vitro degradation patterns of peanut digests by simulating gastric or small intestine milieus $(102,103)$. The pronounced digestion stability of Ara h 2, 6, and specific peptides was linked to IgE-recognition and suggested as triggers of the immune response in-vivo. Those peptide structures might be novel candidates for serological assays, be it as antigens in immunoassays or as references for peptide identification in patient blood. In fact, upon ingestion, peanut allergens are degraded, followed by absorption across biological barriers and distribution via the bloodstream (20, 60, 104-106). The analysis of allergen residues in human samples after peanut ingestion has been recognized as an important challenge $(60,61)$. Recent antibody-based studies, combined with removal of interfering endogenous immunoglobulins, succeeded to detect peanut allergens in a reliable fashion (62). Proteomic analyses of such peripheral allergen peptides, together with MS-based analyses of serological metabolomics signatures (68), might be promising avenues toward molecular endotyping of peanutallergic patients, and toward marker discovery for phenotype prediction (Figure 1).

\section{Immunological Endotyping Non-Omics}

Deep immunological endotyping, including aspects of the genome, epigenome, transcriptome and proteome provided 
TABLE 1 | Summary of the main approaches (non-/omics) toward phenotypic biomarkers in peanut allergy based on molecular, immunological and commensal endotyping.

\begin{tabular}{|c|c|c|c|c|}
\hline Method & Biomarker research area & Interpretation in peanut allergy & $\mathrm{CE}^{*}$ & References ${ }^{\star \star}$ \\
\hline \multicolumn{5}{|c|}{ Molecular endotyping } \\
\hline \multicolumn{5}{|c|}{ Non-omics } \\
\hline \multirow[t]{7}{*}{ Immunoassays } & $\begin{array}{l}\text { Serum lgE to Ara h 2, Ara h } 6 \text { (less } \\
\text { Ara h } 1 \text { and Ara h 3) }\end{array}$ & $\begin{array}{l}\text { Primary peanut allergy; often, presence of slgE and high titers (cut-off titers } \\
\text { unequivocal) along with severity }\end{array}$ & \# & $\begin{array}{l}(37,38,42- \\
47)\end{array}$ \\
\hline & $\begin{array}{l}\text { Serum IgE to Ara h 10, Ara h 11, Ara } \\
\text { h 14, Ara h } 15\end{array}$ & Primary peanut allergy; often, presence of slgE related to severity & \# & $(48)$ \\
\hline & Serum IgE to Ara h 8 & Primary sensitization to pollen (eg, birch, alder); mostly, mild reactions to peanut & \# & $(49-52)$ \\
\hline & Serum IgE to Ara h 9 & $\begin{array}{l}\text { Primary sensitization to nsLTP (eg, peach Pru p 3); severe reactions to peanut in Ara } h \\
\text { 1-7 negative patients }\end{array}$ & \# & $(53-55)$ \\
\hline & Serum IgE to peanut epitopes & $\begin{array}{l}\text { High diversity of sequential IgE-epitopes (Ara h 1, Ara h 2, Ara h 3) along with more } \\
\text { severity }\end{array}$ & \# & $(38,56-59)$ \\
\hline & $\begin{array}{l}\text { Serum peanut peptides upon in-vivo } \\
\text { ingestion }\end{array}$ & $\begin{array}{l}\text { Digestion-stable Ara h 6-peptides as candidate markers for in-vivo reactivity and } \\
\text { serological proteomics }\end{array}$ & & $(60-63)$ \\
\hline & Serum IgE-bound soluble FceRI & $\begin{array}{l}\text { Soluble FceRI levels together with correlating lgE-titer as putative markers for in-vivo } \\
\text { reactivity and severity }\end{array}$ & & (64) \\
\hline $\begin{array}{l}\text { Integrated } \\
\text { algorithms }\end{array}$ & $\begin{array}{l}\text { Serum lgE to Ara h } 2 \text { and peanut } \\
\text { extract, BAT together with clinical } \\
\text { variables (eg, skin test, asthma) }\end{array}$ & Prediction of risk to experience severe events (symptoms scoring, threshold reactivity) & \# & $(65,66)$ \\
\hline \multicolumn{5}{|c|}{ Allergenomics } \\
\hline \multirow[t]{2}{*}{ Proteomics } & $\begin{array}{l}\text { Simulated digest-derived peanut } \\
\text { peptides }\end{array}$ & $\begin{array}{l}\text { Digestion-stable Ara h 2/Ara h 6-peptides as candidate markers for in-vivo reactivity } \\
\text { and serological assays }\end{array}$ & & $(38,67)$ \\
\hline & Serum metabolomic signatures & $\begin{array}{l}\text { Metabolites (eg, from dysreguated tryptophan metabolism) as candidate markers for } \\
\text { phenotypic severity }\end{array}$ & & (68) \\
\hline \multicolumn{5}{|c|}{ Immunological endotyping } \\
\hline \multicolumn{5}{|l|}{ Non-omics } \\
\hline Immunoassays & PBMC peanut-stimulated $\mathrm{CD} 4^{+} \mathrm{T}$ cells & $\begin{array}{l}\text { Increased Th2 cytokine expression (IL-4, IL-5, IL-9, IL-13) correlating with elevated } \\
\text { peanut-specific IgE-titers and low threshold reactivity }\end{array}$ & \# & (69) $((70))$ \\
\hline \multirow[t]{2}{*}{$\begin{array}{l}\text { Mass } \\
\text { cytometry }\end{array}$} & $\begin{array}{l}\text { Blood peanut-stimulated CD45 }{ }^{+} \text {cells, } \\
\text { basophils (CD63, FceRI, CD23) }\end{array}$ & $\begin{array}{l}\text { Basophil-platelet complexes (CD61, CD141, CD42b) with potential to contributing to } \\
\text { severity and PAF-related anaphylaxis }\end{array}$ & & $(71)((72,73))$ \\
\hline & $\begin{array}{l}\text { PBMC un-/peanut-stimulated CD45 } \\
\text { cells, } 11 \text { cell types within CD4 T-cells, } \\
\text { CD8 T-cells, B-cells, myeloid cells }\end{array}$ & $\begin{array}{l}\text { Increased prevalence of activated B cells }\left(\mathrm{CD} 19^{\text {hi }} \mathrm{HLDR}{ }^{\text {hi }}\right) \text { and peanut-specific CD4 T } \\
\text { cells }\left(\mathrm{CD} 4 \mathrm{OL}^{+} \mathrm{CD} 69^{+} \text {, memory } \mathrm{CD} 45 \mathrm{RA}^{-} \mathrm{CCR} 7^{+/}\right) \text {correlating with in-vivo reactivity }\end{array}$ & & $(74)$ \\
\hline \multirow[t]{6}{*}{ Flow cytometry } & $\begin{array}{l}\text { Blood peanut-/anti-lgE-induced } \\
\text { CD63 }^{\text {high }} \text { basophils (\%) }\end{array}$ & $\begin{array}{l}\text { Reduced basophil response and FceR-expression, together with low slgE, as putative } \\
\text { markers for severity }\end{array}$ & & $\begin{array}{l}(52)((75-77) \\
(78,79))\end{array}$ \\
\hline & $\begin{array}{l}\text { PBMC peanut-stimulated CD154 }{ }^{+} \mathrm{T} \\
\text { cells }\end{array}$ & $\begin{array}{l}\text { Increased cytokine-positive } \mathrm{CD} 4^{+} \mathrm{T} \text { cell counts }\left(\mathrm{CD} 154^{+} \mathrm{CD} 4^{+} \mathrm{IL}-4^{+} \text {or } \mathrm{IL}-13^{+}\right) \\
\text {correlating with increased slgE-titers and clinical threshold reactivity }\end{array}$ & \# & $(69,70,80)$ \\
\hline & & $\begin{array}{l}\text { Increase of CD4 }{ }^{+} \mathrm{T} \text { cell homing populations (CCR4: skin, lung; CCR6: mucosa; } \\
\text { CXCR5: B cell follicle) correlating with clinical reactivity }\end{array}$ & \# & $\begin{array}{l}(69,81),((82, \\
83))\end{array}$ \\
\hline & & $\begin{array}{l}\text { Increase of IL-2-dependent CD } 154^{+} \text {Treg cells with regulatory } \\
\left(\mathrm{CD} 3^{+} \mathrm{CD} 4^{+} \mathrm{CD} 25^{\mathrm{h}} \mathrm{iCD} 127^{\mathrm{low}} \text { FoxP3 } 3^{+}\right) \text {and memory markers (CD45RO) correlating with } \\
\text { clinical threshold reactivity }\end{array}$ & \# & (69) \\
\hline & & $\begin{array}{l}\text { Increased coefficient of Teff/Treg }\left(\mathrm{CD} 25^{+} \mathrm{CD} 127^{+/-}\right) \text {correlating with clinical threshold } \\
\text { reactivity }\end{array}$ & \# & (70) ((83)) \\
\hline & $\begin{array}{l}\text { PBMC peanut/peptide-stimulated T } \\
\text { cells }\end{array}$ & $\begin{array}{l}\text { Phenotype Th2 shift (expression gut-homing factor Integrin } \beta T \text {, CRTh2) relating to } \\
\text { clinical reactivity }\end{array}$ & & (84) \\
\hline \multicolumn{5}{|c|}{ Multimodal omics } \\
\hline \multirow[t]{2}{*}{ Genomics } & $\begin{array}{l}\text { PBMC-derived peanut-activated } \\
\text { CD154 }^{+} \text {Teff/Treg }\left(C D 25^{+} \text {CD127 } 7^{+/}\right)\end{array}$ & $\begin{array}{l}\text { Increased diversity of the peanut-specific TCR } \beta \text { repertoire (CDR3 sequences) and } \\
\text { enrichment in the Teff compartment, in correlation with low threshold reactivity }\end{array}$ & \# & (70) \\
\hline & Salivary DNA-based HLA gene SNPS & $\begin{array}{l}\text { With the HLA-DQB1 region confirmed as a risk factor for clinical allergy, increased } \\
\text { odds ratios for SNPs in HLA (rs17612852, rs9275596, and rs1612904) correlate with } \\
\text { low reaction severity }\end{array}$ & \# & $\begin{array}{l}\text { (85) }((86)(87, \\
88))\end{array}$ \\
\hline \multirow[t]{2}{*}{ Transcriptomics } & $\begin{array}{l}\text { PBMC-derived peanut-activated } \\
\text { CD154 }{ }^{+} \mathrm{T} \text { cells }\end{array}$ & $\begin{array}{l}\text { Differential gene expression patterns according to clinical phenotypes stratified by } \\
\text { threshold reactivity, pronounced gene expression associated to Th2 and Th17 cells in } \\
\text { individuals with low threshold reactivity }\end{array}$ & \# & (69) $((70))$ \\
\hline & $\begin{array}{l}\text { Whole blood cells during food } \\
\text { challenge }\end{array}$ & $\begin{array}{l}\text { Leucocyte compositional changes (naive B cells/CD4 }{ }^{+} \mathrm{T} \text { cells, } \text {, neutrophils) associated } \\
\text { with severity, upregulated "peanut severity genes" (eg, neutrophil-related function, } \\
\text { leucocyte function) correlating with severity scores }\end{array}$ & \# & (89) $((90))$ \\
\hline Epigenetics & Whole blood CD4+ Iymphocytes & $\begin{array}{l}\text { "Peanut severity CpG" methylation associated with "peanut severity genes" (eg, } \\
\text { immune response, chemotaxis, macroautophagy regulation; moderator genes NFKBIA } \\
\text { and ARG1) and clinical reactivity scores }\end{array}$ & \# & (90) \\
\hline
\end{tabular}


TABLE 1 | Continued

\begin{tabular}{|c|c|c|c|c|}
\hline Method & Biomarker research area & Interpretation in peanut allergy & $\mathrm{CE}^{\star}$ & References \\
\hline \multicolumn{5}{|c|}{ Commensal endotyping } \\
\hline \multicolumn{5}{|l|}{ Non-omics } \\
\hline Flow cytometry & Fecal microbiome & $\begin{array}{l}\text { Increased IgE-binding to fecal microbes suggesting an anti-commensal Th2 response } \\
\text { contributing to the clinical reactivity and phenotype outcome }\end{array}$ & & (91) \\
\hline \multicolumn{5}{|c|}{ Microbiomics and gut issue typing } \\
\hline \multirow[t]{4}{*}{ Genomics } & Fecal microbiome & Decreased microbial richness associated with PA & & (92) \\
\hline & & Increased alpha-diversity in low responsive individuals & & (93) \\
\hline & & $\begin{array}{l}\text { Bacteroidales, especially Bacteroides fragili increased in PA, Clostridium sp increased } \\
\text { in low threshold; high Oscillosiraceae sp, Lachnospiraceae sp, Ruminococcaceae sp, } \\
\text { Frimicutes sp and Bacteroides sp correlating with low threshold reactivity }\end{array}$ & & $(92,93)$ \\
\hline & & $\begin{array}{l}\text { Clostridiales abundance decreased in PA, potentially leading to a decrease in } \\
\text { protective ROR- } \gamma \text { t+ iTreg cell populations }\end{array}$ & & $(91,92)$ \\
\hline Transcriptomics & $\begin{array}{l}\text { Gut tissue-derived peanut-specific } \\
\text { lgE+ plasma cells }\end{array}$ & $\begin{array}{l}\text { Local class switch resulting in lgE+ B cell counts correlating with serum slgE-titers; at } \\
\text { the gut microbiome interface, local lgE-reservoir for mast cell FceRl-coating and thus, } \\
\text { candidate factors triggering clinical reactivity profiles }\end{array}$ & & (94) \\
\hline
\end{tabular}

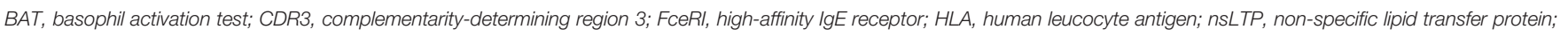
PBMC, peripheral blood mononuclear cell; slgE, specific IgE; SNP, single nucleotide polymorphism; TCR, T cell receptor; Teff, effector T cell; Treg, regulatory T cell.



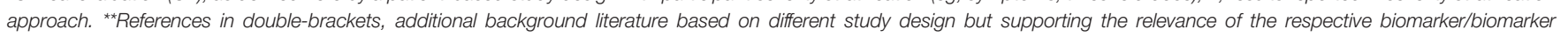
approach.

insights in the immune landscape of PA phenotypes, with prospect of future multimodal omics, meaning the integration of heterogeneous data from those sources.

Tordesillas et al. studied the in-vitro activation of granulocytes (basophils, eosinophils, neutrophils), monocytes, dendritic cells, T cells, B cells and NK cells in whole blood using single-cell mass cytometry (71). More B cells and eosinophils but less neutrophils were found in resting $\mathrm{CD} 45^{+}$cells from peanutallergic vs healthy individuals. After stimulation with peanut protein, the highest response was observed for basophils (CD16, CD23, CD63), but also monocytes, dendritic cells and neutrophils became activated, pointing to an emerging role of these myeloid cells related to clinical PA. Elevated plasma PAF levels had been associated with increased severity of PA earlier $(72,73)$. Basophils were found to form physical complexes with platelets (CD61, CD141, CD42b) upon peanut activation, suggesting a novel way of PAF-related anaphylaxis (Figure 1) (71). Neeland et al. applied mass cytometry to study peripheral immune signatures associated with clinical PA, using peripheral blood mononuclear cells (PBMC) from peanut-allergic and controls (74). Allergic infants distinguished from sensitized infants by increased prevalence of a B cell cluster $\left(\mathrm{CD} 19^{\text {hi }} \mathrm{HLDR}^{\mathrm{hi}}\right)$. Upon in-vitro stimulation with peanut protein, increased levels of CD4 T cells $\left(\mathrm{CD}_{40 \mathrm{~L}^{+}} \mathrm{CD} 9^{+}\right.$, memory $\left.\mathrm{CD} 45 \mathrm{RA}^{-} \mathrm{CCR}^{+/-}\right)$discriminated peanut-allergic from controls.

Other studies focused on analyzing the T cell compartment in PA (81, 107-109). Chiang et al. compared peanut-allergic (OFC positive at $<1 \mathrm{~g}$ cumulative peanut dose), high-threshold (OFC negative at $\leq 1 \mathrm{~g}$ cumulative peanut dose but $\operatorname{sigE}$ to peanut and clinical PA history), and healthy individuals (69). In-vitro PBMC stimulation induced a significant increase in peanut-responsive $\mathrm{T}$ cells $\left(\mathrm{CD} 154^{+} \mathrm{CD} 4^{+}\right)$and significant cytokine increases (mainly IL4, IL-13) in peanut-allergic patients only. Cytokine-positive T cell counts $\left(\mathrm{CD} 154^{+} \mathrm{CD} 4^{+} \mathrm{IL}-4^{+}\right.$or $\left.\mathrm{IL}-13^{+}\right)$correlated with sIgE-titers. Peanut-allergic patients had higher shares of peanut-activated Th2 cells with homing markers (CCR4: skin, lung; CCR6: mucosa;
CXCR5: B cell follicle) as compared to controls. Peanutresponsive $\mathrm{T}$ cells presented with surface marker heterogeneity as well as enrichment for effector memory $\mathrm{T}$ cells (CD45RO) and regulatory marker expression $\left(\mathrm{CD}^{+} \mathrm{CD}^{+} \mathrm{CD} 25^{\text {hi }} \mathrm{CD} 127^{\text {low }} \mathrm{FoxP}^{+}\right.$, delayed IL-2-dependent activation). RNA sequencing of peanutactivated $\mathrm{T}$ cells confirmed proinflammatory Th2-polarization with multicytokine expression. This study pointed to the heterogeneous nature of the peanut-specific Th2 response in presence of functional Treg cells. The lack of T cell reactivity (peanut-specific Th2, Treg) in high-threshold individuals discriminated those from peanut-allergic individuals. In a similar approach, Ruiter et al. investigated the T cell response to peanut protein comparing peanut-allergic (OFC positive at $<0.5 \mathrm{~g}$ cumulative peanut dose) and hyporeactive (OFC negative at $\leq 0.5 \mathrm{~g}$ cumulative peanut dose but clinical PA history) individuals (70). Compared to hyporeactive patients, stimulated PBMC from peanut-allergic patients showed a higher $\mathrm{CD} 154^{+} \mathrm{CD} 4^{+}$ $\mathrm{T}$ cells response and stimulation index correlating with elevated peanut-specific $\mathrm{CD}^{+} \mathrm{T}$ cell and complementarity determining region 3 (CRD3; $\mathrm{T}$ cell receptor domain identified by RNA sequencing) counts. Indeed, CDR3 constitutes the most critical region responsible for recognizing processed antigens $(110,111)$. Some peanut-specific CRD3 (17\%) were found exclusively in $\mathrm{CD} 154^{+} \mathrm{CD} 4^{+} \mathrm{T}$ cells from peanut-allergic individuals (70). CRD3 were also more variable in effector $\mathrm{T}$ cells $\left(\mathrm{CD} 25^{+} \mathrm{CD} 127^{+}\right)$than Treg cells $\left(\mathrm{CD} 25^{++} \mathrm{CD} 127^{-}\right)$, suggesting skewing toward a compartment with expanded effector $\mathrm{T}$ cell repertoire in allergic but not in hyporeactive patients. The ratio of peanut-specific effector $\mathrm{T}$ cell vs Treg discriminated individuals stratified by threshold doses. The pronounced clinical reactivity of peanut-allergic patients was concluded to correlate to peanut-specific effector $\mathrm{T}$ cells characteristics (frequency, proportion, reactivity), rather than a defective Treg response (Figure 1).

\section{Multimodal Omics}

Gene sequencing studies provided insights into FA immune regulation and epithelial barrier function $(112,113)$. Genome- 




FIGURE 1 | Endotyping of peanut-allergic patients: from selected, established to newly discovered approaches. The association of IgE-signatures (IgG-profiles not shown/reviewed in text) and basophil reactivity profiles with clinical phenotypes is widely established. Research fields on peripheral allergen tracing, deep immune typing (eg, T cells), gene expression/modification as well as local gut immune responses and gut microbiome-host interactions represent putative endotyping axes which require further investigations and finally, systems-level integration in future studies. Incr., increased; PA, peanut allergy.

wide association studies reported on loci correlated to specific FAs (Table 1) (85-87, 114). Beyond aspects of disease susceptibility, recent studies focused on genes involved in acute inflammation in PA patients. Watson et al. analyzed the time-resolved transcriptome in peripheral blood sampled from peanut-allergic individuals during OFC (at baseline, $2 \mathrm{~h} / 4 \mathrm{~h}$ later), comparing peanut vs placebo (89). Indeed, specific gene expression changes were induced by peanut intake. Gene upregulation was commonly found $(1,411 / 2,168$ genes) correlating with evolving peanutinduced inflammation. In leucocyte cell subsets after deconvolution, resting macrophages (M0) and neutrophilic granulocytes increased while naive $\mathrm{CD}^{+} \mathrm{T}$ cells decreased during OFC. Genes associated with peanut-allergic reactions were mostly found in a co-expression module with upregulated genes related to inflammatory processes. Six key driver genes were identified (3/6 with established role in inflammation) as modulators of the peanut-reactive co-expression module. The data-driven approach on genes involved in peanut-allergic reactions was further developed by Do et al. using transcriptome analysis during OFC (at baseline, $2 \mathrm{~h} / 4 \mathrm{~h}$ later), in combination with baseline epigenomic profiling (90). The participants' clinical reactivity was stratified by threshold-weighted severity grades. More than 300 genes ("peanut severity genes") had significant expression changes during OFC and were found to be associated with reaction severity. Biological processes related to upregulated peanut severity genes clustered by function, mostly around neutrophils (activation, degranulation, neutrophil-mediated immunity). With pronounced reaction severity, neutrophilic granulocytes increased also in number while naive $\mathrm{CD} 4^{+} \mathrm{T}$ cells and naive $\mathrm{B}$ cells decreased significantly during the course of OFC. Most peanut severity genes clustered together by coexpression. Gene interaction network analysis indicated the central role of two genes, NFKBIA (NF-kappa-B-inhibitor alpha, a regulator protein) and ARG1 (arginase, a catabolic enzyme and immune regulator), on reaction severity. Epigenetic modification correlating with reaction severity, as measured by methylation signatures of $\mathrm{CpG}$ dinucleotides in $\mathrm{CD}^{+}$ lymphocytes, was found for more than $200 \mathrm{CpGs}$ ("peanut severity CpG”). A causal relationship between methylation and peanut severity genes gene expression was established, pointing 
further to the relevance of epigenetic modifications in the context reaction severity.

\section{Commensal Endotyping}

The gut represents the largest interface for the interaction between the human body and food allergens. There is a constant regulatory interaction between the immune system and the intestinal microbiome (115). The microbiome might promote Th2-immunity to food by regulating eosinophils (frequency, function) in the gut (116).

\section{Non-Omics}

More recently, sIgE-binding to commensal bacteria was discovered in food-allergic children, suggesting structural similarities between food allergens and microbial structures (91). Molecular mimicry of the microbiome plays a role in a number of inflammatory diseases, such as celiac disease. Here, structures on P. fluorescens, a commensal which is overrepresented in celiac disease, have been found to mimic human leukocyte antigen (HLA) locus HLA-DQ2.5- and activate mucosal T cells, suggesting a pathological dysfunction of the gut barrier (117). First studies comparing amino-acid sequence similarities between known food allergens and microbiome data revealed conserved regions of $\mathrm{T}$-cell immune recognition on commensal bacteria (118). Carrasco Pro et al. further showed similarities between human microbiome sequences and inhalation allergens (119).

\section{Microbiomics and Gut Tissue Typing}

The adaptive immune response is influenced by microbial interactions with secreted IgA (120), together with lower richness and lower local species diversity (alpha diversity), accompanied by a dysbiosis of commensal strains $(92,93)$. A previous study demonstrated that peanut allergy is marked by higher Bacteroidales, especially Bacteroides fragilis and reduced Clostridiales abundance (92). Low threshold reactivity to peanut has been connected to an increase in Clostridium sp, Oscillosiraceae sp, Lachnospiraceae sp, Ruminococcaceae sp, Frimicutes sp, and Bacteroides sp (91-93).

At which gastrointestinal sites immune dysregulation and allergic sensitization might develop is unexplored. Recently, large numbers of allergen-specific B cells were described in the gut (stomach, duodenum) of peanut-allergic patients (94). These $\operatorname{IgE}^{+}$cells are rarely found in the blood $(121,122)$. Gut $\operatorname{IgE}^{+} \mathrm{B}$ cells counts were found to correlate with serum IgE-titer concentrations. Importantly, inter-individual variations in this local $\operatorname{IgE}^{+} \mathrm{B}$ but also variable mast cell IgE-loading by different $\operatorname{IgE}^{+} \mathrm{B}$ clones might explain differential reaction phenotypes in peanut-allergic patients' reservoir (Figure 1). The high number of $\mathrm{IgE}^{+} \mathrm{B}$ cells in the gut combined with increased intestinal permeability might explain the high sIgE-levels found in fecal samples of food-allergic patients (123).

These findings give an idea of a new mechanism in which the microbiome may initiate, trigger and influence allergic reactions. This in turn may lead to novel ways to stratify patients, due to their metaproteomic profile, as has been shown for other inflammatory diseases $(124,125)$.

\section{CONCLUSION: PERSPECTIVE TOWARD NEW INTEGRATIVE APPROACHES}

Deciphering the immunological response to food proteins shall enable the stratification of patients into reaction endotypes, for advanced understanding of their phenotypic heterogeneity. The ambitious but ultimate goal will be to identify clinically useful predictors for allergic reactions to food, with emphasis on predicting clinical outcome, severity and threshold dose, upon allergen exposure in order to adapt avoidance protocols and symptomatic medication $(15,126)$. Recent PA-studies demonstrated the complexity of the immune mechanism, as investigated during simulated allergen-specific stimulations or during the course of clinical reactions $(71,74,89,90)$. Several studies did even compare immune targets in individuals with variable clinical reactions, based on severity or sensitivity $(69,70$, 90). To explain clinical manifestations of reaction phenotypes, various aspects are considered of fundamental relevance, including the molecular IgE-signature/-repertoire, the potency/ repertoire of effector cells, the kinetics of allergen degradation/ absorption, allergen-specific T cell reactivity profiles, genes/ methylations and aspects of the gut microbiome including composition and host interaction (Figure 1). The availability of multiple omics technologies, proteomics, high-dimensional mass cytometry, transcriptomics and epigenomics, allowed identifying promising molecular and immunological targets for future human studies. Taken individually, each omics-approach has assets and drawbacks (reviewed by $(127,128)$ but together they might unfold their full potential. Unbiased machinelearning, integrated data analysis of heterogeneous datasets as well as network-based approaches will be required to establish algorithms for providing insights in disease pathophysiology and for inferring biomarkers or biomarker signatures being predictive for reaction phenotypes $(33,127,129,130)$. Finally, those insights shall advance the stratification of individuals prior to selection for oral immunotherapy or early food introduction for prevention, both pioneer areas research in PA $(131,132)$.

\section{AUTHOR CONTRIBUTIONS}

RC and JK wrote the manuscript. MS, FC-M, and CB-J revised the manuscript as to clinical content. $\mathrm{CH}, \mathrm{PW}, \mathrm{PS}$, and MO provided critical feedback to the manuscript concept and scientific content. AK developed the review concept together with $\mathrm{RC} / \mathrm{JK}$ and helped to shape the manuscript. All authors contributed to the article and approved the submitted version.

\section{FUNDING}

Supported by the Luxembourg National Research Fund on PRIDE program grants PRIDE/11012546/NEXTIMMUNE and PRIDE17/11823097/MICROH; supported by the Personalized Medicine Consortium grant APSIS, PMC/2017/02 and by the Ministry of Research, Luxembourg. 


\section{REFERENCES}

1. Muraro A, Werfel T, Hoffmann-Sommergruber K, Roberts G, Beyer K, Bindslev-Jensen C, et al. EAACI food allergy and anaphylaxis guidelines: diagnosis and management of food allergy. Allergy (2014) 69(8):1008-25. doi: $10.1111 /$ all.12429

2. Sicherer SH, Sampson HA. Food allergy: A review and update on epidemiology, pathogenesis, diagnosis, prevention, and management. J Allergy Clin Immunol (2018) 141(1):41-58. doi: 10.1016/j.jaci.2017.11.003

3. Anvari S, Miller J, Yeh CY, Davis CM. IgE-Mediated Food Allergy. Clin Rev Allergy Immunol (2019) 57(2):244-60. doi: 10.1007/s12016-018-8710-3

4. Gupta RS, Springston EE, Warrier MR, Smith B, Kumar R, Pongracic J, et al. The prevalence, severity, and distribution of childhood food allergy in the United States. Pediatrics (2011) 128(1):e9-17. doi: 10.1542/peds.2011-0204

5. Gupta RS, Warren CM, Smith BM, Jiang J, Blumenstock JA, Davis MM, et al. Prevalence and Severity of Food Allergies Among US Adults. JAMA Netw Open (2019) 2(1):e185630. doi: 10.1001/jamanetworkopen.2018.5630

6. Fox M, Mugford M, Voordouw J, Cornelisse-Vermaat J, Antonides G, de la Hoz Caballer B, et al. Health sector costs of self-reported food allergy in Europe: a patient-based cost of illness study. Eur J Public Health (2013) 23 (5):757-62. doi: 10.1093/eurpub/ckt010

7. Polloni L, Muraro A. Anxiety and food allergy: A review of the last two decades. Clin Exp Allergy (2020) 50(4):420-41. doi: 10.1111/cea.13548

8. Eiwegger T, Hung L, San Diego KE, O'Mahony L, Upton J. Recent developments and highlights in food allergy. Allergy (2019) 74(12):235567. doi: 10.1111/all.14082

9. Hammad H, Lambrecht BN. Barrier Epithelial Cells and the Control of Type 2 Immunity. Immunity (2015) 43(1):29-40. doi: 10.1016/j.immuni. 2015.07.007

10. Chinthrajah RS, Hernandez JD, Boyd SD, Galli SJ, Nadeau KC. Molecular and cellular mechanisms of food allergy and food tolerance. J Allergy Clin Immunol (2016) 137(4):984-97. doi: 10.1016/j.jaci.2016.02.004

11. Sampath V, Tupa D, Graham MT, Chatila TA, Spergel JM, Nadeau KC. Deciphering the black box of food allergy mechanisms. Ann Allergy Asthma Immunol (2017) 118(1):21-7. doi: 10.1016/j.anai.2016.10.017

12. Valenta R, Hochwallner H, Linhart B, Pahr S. Food allergies: the basics. Gastroenterology (2015) 148(6):1120-31.e4. doi: 10.1053/j.gastro.2015.02.006

13. Tordesillas L, Berin MC, Sampson HA. Immunology of Food Allergy. Immunity (2017) 47(1):32-50. doi: 10.1016/j.immuni.2017.07.004

14. Sampson HA, O’Mahony L, Burks AW, Plaut M, Lack G, Akdis CA. Mechanisms of food allergy. J Allergy Clin Immunol (2018) 141(1):11-9. doi: 10.1016/j.jaci.2017.11.005

15. Chong KW, Ruiz-Garcia M, Patel N, Boyle RJ, Turner PJ. Reaction phenotypes in IgE-mediated food allergy and anaphylaxis. Ann Allergy Asthma Immunol (2020) 124(5):473-8. doi: 10.1016/j.anai.2019.12.023

16. Hourihane JO, Allen KJ, Shreffler WG, Dunngalvin G, Nordlee JA, Zurzolo GA, et al. Peanut Allergen Threshold Study (PATS): Novel single-dose oral food challenge study to validate eliciting doses in children with peanut allergy. J Allergy Clin Immunol (2017) 139(5):1583-90. doi: 10.1016/ j.jaci.2017.01.030

17. Ruiz-Garcia M, Bartra J, Alvarez O, Lakhani A, Patel S, Tang A, et al. Cardiovascular changes during peanut-induced allergic reactions in human subjects. J Allergy Clin Immunol (2020). doi: 10.1016/j.jaci.2020.06.033

18. Ballmer-Weber BK, Fernandez-Rivas M, Beyer K, Defernez M, Sperrin M, Mackie AR, et al. How much is too much? Threshold dose distributions for 5 food allergens. J Allergy Clin Immunol (2015) 135(4):964-71. doi: 10.1016/ j.jaci.2014.10.047

19. Glaumann S, Nopp A, Johansson SGO, Borres MP, Nilsson C. Oral Peanut Challenge Identifies an Allergy but the Peanut Allergen Threshold Sensitivity Is Not Reproducible. PloS One (2013) 8(1):e53465. doi: 10.1371/journal.pone.0053465

20. Poulsen LK, Jensen BM, Esteban V, Garvey LH. Beyond IgE-When Do IgECrosslinking and Effector Cell Activation Lead to Clinical Anaphylaxis? Front Immunol (2017) 8:871. doi: 10.3389/fimmu.2017.00871

21. Dua S, Ruiz-Garcia M, Bond S, Durham SR, Kimber I, Mills C, et al. Effect of sleep deprivation and exercise on reaction threshold in adults with peanut allergy: A randomized controlled study. J Allergy Clin Immunol (2019) 144 (6):1584-94.e2. doi: 10.1016/j.jaci.2019.06.038
22. Savage J, Sicherer S, Wood R. The Natural History of Food Allergy. J Allergy Clin Immunol Pract (2016) 4(2):196-203. doi: 10.1016/j.jaip.2015.11.024

23. Verhoeckx KCM, van Broekhoven S, den Hartog-Jager CF, Gaspari M, de Jong GAH, Wichers HJ, et al. House dust mite (Der p 10) and crustacean allergic patients may react to food containing Yellow mealworm proteins. Food Chem Toxicol (2014) 65:364-73. doi: 10.1016/j.fct.2013.12.049

24. Ballardini N, Nopp A, Hamsten C, Vetander M, Melén E, Nilsson C, et al. Anaphylactic Reactions to Novel Foods: Case Report of a Child With Severe Crocodile Meat Allergy. Pediatrics (2017) 139(4):e20161404. doi: 10.1542/ peds.2016-1404

25. Verhoeckx K, Lindholm Bøgh K, Constable A, Epstein MM, Hoffmann Sommergruber K, Holzhauser T, et al. COST Action 'ImpARAS': what have we learnt to improve food allergy risk assessment. A summary of a 4 year networking consortium. Clin Transl Allergy (2020) 10:13. doi: 10.1186/ s13601-020-00318-x

26. Matricardi PM, Kleine-Tebbe J, Hoffmann HJ, Valenta R, Hilger C, Hofmaier S, et al. EAACI Molecular Allergology User's Guide. Pediatr Allergy Immunol (2016) 27 Suppl 23:1-250. doi: 10.1111/pai.12563

27. Akkerdaas J, Totis M, Barnett B, Bell E, Davis T, Edrington T, et al. Protease resistance of food proteins: a mixed picture for predicting allergenicity but a useful tool for assessing exposure. Clin Trans Allergy (2018) 8(1):30. doi: 10.1186/s13601-018-0216-9

28. Kalic T, Morel-Codreanu F, Radauer C, Ruethers T, Taki AC, Swoboda I, et al. Patients Allergic to Fish Tolerate Ray Based on the Low Allergenicity of Its Parvalbumin. J Allergy Clin Immunol Pract (2019) 7(2):500-8.e11. doi: 10.1016/j.jaip.2018.11.011

29. Klueber J, Costa J, Randow S, Codreanu-Morel F, Verhoeckx K, BindslevJensen C, et al. Homologous tropomyosins from vertebrate and invertebrate: Recombinant calibrator proteins in functional biological assays for tropomyosin allergenicity assessment of novel animal foods. Clin Exp Allergy (2020) 50(1):105-16. doi: 10.1111/cea.13503

30. Trompette A, Divanovic S, Visintin A, Blanchard C, Hegde RS, Madan R, et al. Allergenicity resulting from functional mimicry of a Toll-like receptor complex protein. Nature (2009) 457(7229):585-8. doi: 10.1038/ nature 07548

31. Palladino C, Narzt MS, Bublin M, Schreiner M, Humeniuk P, Gschwandtner M, et al. Peanut lipids display potential adjuvanticity by triggering a proinflammatory response in human keratinocytes. Allergy (2018) 73(8):1746-9. doi: 10.1111/all.13475

32. Alessandri C, Ferrara R, Bernardi ML, Zennaro D, Tuppo L, Giangrieco I, et al. Molecular approach to a patient's tailored diagnosis of the oral allergy syndrome. Clin Trans Allergy (2020) 10(1):22. doi: 10.1186/s13601-02000329-8

33. Muraro A, Arasi S. Biomarkers in Food Allergy. Curr Allergy Asthma Rep (2018) 18(11):64. doi: 10.1007/s11882-018-0816-4

34. Perry TT, Matsui EC, Conover-Walker MK, Wood RA. Risk of oral food challenges. J Allergy Clin Immunol (2004) 114(5):1164-8. doi: 10.1016/ j.jaci.2004.07.063

35. Sørensen M, Kuehn A, Mills ENC, Costello CA, Ollert M, Småbrekke L, et al. Cross-reactivity in fish allergy: A double-blind, placebo-controlled foodchallenge trial. J Allergy Clin Immunol (2017) 140(4):1170-2. doi: 10.1016/ j.jaci.2017.03.043

36. Datema MR, van Ree R, Asero R, Barreales L, Belohlavkova S, de Blay F, et al. Component-resolved diagnosis and beyond: Multivariable regression models to predict severity of hazelnut allergy. Allergy (2018) 73(3):549-59. doi: $10.1111 /$ all.13328

37. Nilsson C, Berthold M, Mascialino B, Orme ME, Sjölander S, Hamilton RG. Accuracy of component-resolved diagnostics in peanut allergy: Systematic literature review and meta-analysis. Pediatr Allergy Immunol (2020) 31 (3):303-14. doi: 10.1111/pai.13201

38. Flinterman AE, Knol EF, Lencer DA, Bardina L, den Hartog Jager CF, Lin J, et al. Peanut epitopes for IgE and IgG4 in peanut-sensitized children in relation to severity of peanut allergy. J Allergy Clin Immunol (2008) 121 (3):737-43.e10. doi: 10.1016/j.jaci.2007.11.039

39. Cerecedo I, Zamora J, Shreffler WG, Lin J, Bardina L, Dieguez MC, et al. Mapping of the IgE and IgG4 sequential epitopes of milk allergens with a peptide microarray-based immunoassay. J Allergy Clin Immunol (2008) 122 (3):589-94. doi: 10.1016/j.jaci.2008.06.040 
40. Nassiri M, Eckermann O, Babina M, Edenharter G, Worm M. Serum levels of $9 \alpha, 11 \beta-$ PGF2 and cysteinyl leukotrienes are useful biomarkers of anaphylaxis. J Allergy Clin Immunol (2016) 137(1):312-4.e7. doi: 10.1016/ j.jaci.2015.07.001

41. Chan ES, Dinakar C, Gonzales-Reyes E, Green TD, Gupta R, Jones D, et al. Unmet needs of children with peanut allergy: Aligning the risks and the evidence. Ann Allergy Asthma Immunol (2020) 124(5):479-86. doi: 10.1016/ j.anai.2020.01.016

42. Eller E, Bindslev-Jensen C. Clinical value of component-resolved diagnostics in peanut-allergic patients. Allergy (2013) 68(2):190-4. doi: 10.1111/all.12075

43. Hemmings O, Du Toit G, Radulovic S, Lack G, Santos AF. Ara h 2 is the dominant peanut allergen despite similarities with Ara h 6. J Allergy Clin Immunol (2020) 3:621-30. doi: 10.1016/j.jaci.2020.03.026

44. Cottel N, Saf S, Bourgoin-Heck M, Lambert N, Amat F, Poncet P, et al. Two Different Composite Markers Predict Severity and Threshold Dose in Peanut Allergy. J Allergy Clin Immunol Pract (2020) 1:275-82. doi: 10.1016/ j.jaip.2020.09.043

45. Faber MA, Donné I, Herrebosch E, Sabato V, Hagendorens MM, Bridts CH, et al. Sensitization profiles to peanut allergens in Belgium; cracking the code in infants, children and adults. Acta Clin Belg (2016) 71(1):32-7. doi: 10.1080/17843286.2015.1109170

46. Giovannini M, Comberiati P, Piazza M, Chiesa E, Piacentini GL, Boner A, et al. Retrospective definition of reaction risk in Italian children with peanut, hazelnut and walnut allergy through component-resolved diagnosis. Allergol Immunopathol (Madr) (2019) 47(1):73-8. doi: 10.1016/j.aller.2018.03.009

47. Kaur N, Mehr S, Katelaris C, Wainstein B, Altavilla B, Saad R, et al. Added Diagnostic Value of Peanut Component Testing: A Cross-Sectional Study in Australian Children. J Allergy Clin Immunol Pract (2020) 1:245-53. doi: 10.1016/j.jaip.2020.08.060

48. Schwager C, Kull S, Behrends J, Röckendorf N, Schocker F, Frey A, et al. Peanut oleosins associated with severe peanut allergy-importance of lipophilic allergens for comprehensive allergy diagnostics. J Allergy Clin Immunol (2017) 140(5):1331-8.e8. doi: 10.1016/j.jaci.2017.02.020

49. Martinet J, Couderc L, Renosi F, Bobée V, Marguet C, Boyer O. Diagnostic Value of Antigen-Specific Immunoglobulin E Immunoassays against Ara h 2 and Ara h 8 Peanut Components in Child Food Allergy. Int Arch Allergy Immunol (2016) 169(4):216-22. doi: 10.1159/000446181

50. Mittag D, Akkerdaas J, Ballmer-Weber BK, Vogel L, Wensing M, Becker W-M, et al. Ara h 8, a Bet v 1-homologous allergen from peanut, is a major allergen in patients with combined birch pollen and peanut allergy. J Allergy Clin Immunol (2004) 114(6):1410-7. doi: 10.1016/j.jaci.2004.09.014

51. Asarnoj A, Nilsson C, Lidholm J, Glaumann S, Östblom E, Hedlin G, et al. Peanut component Ara h 8 sensitization and tolerance to peanut. J Allergy Clin Immunol (2012) 130(2):468-72. doi: 10.1016/j.jaci.2012.05.019

52. Song Y, Wang J, Leung N, Wang LX, Lisann L, Sicherer SH, et al. Correlations between basophil activation, allergen-specific IgE with outcome and severity of oral food challenges. Ann Allergy Asthma Immunol (2015) 114(4):319-26. doi: 10.1016/j.anai.2015.01.006

53. Lauer I, Dueringer N, Pokoj S, Rehm S, Zoccatelli G, Reese G, et al. The nonspecific lipid transfer protein, Ara h 9 , is an important allergen in peanut. Clin Exp Allergy (2009) 39(9):1427-37. doi: 10.1111/j.1365-2222.2009. 03312.x

54. Romano A, Scala E, Rumi G, Gaeta F, Caruso C, Alonzi C, et al. Lipid transfer proteins: the most frequent sensitizer in Italian subjects with fooddependent exercise-induced anaphylaxis. Clin Exp Allergy (2012) 42 (11):1643-53. doi: 10.1111/cea.12011

55. Garcia-Blanca A, Aranda A, Blanca-Lopez N, Perez D, Gomez F, Mayorga C, et al. Influence of age on $\operatorname{IgE}$ response in peanut-allergic children and adolescents from the Mediterranean area. Pediatr Allergy Immunol (2015) 26 (6):497-502. doi: 10.1111/pai.12418

56. Shreffler WG, Beyer K, Chu T-HT, Burks AW, Sampson HA. Microarray immunoassay: Association of clinical history, in vitro IgE function, and heterogeneity of allergenic peanut epitopes. J Allergy Clin Immunol (2004) 113(4):776-82. doi: 10.1016/j.jaci.2003.12.588

57. Lin J, Bruni FM, Fu Z, Maloney J, Bardina L, Boner AL, et al. A bioinformatics approach to identify patients with symptomatic peanut allergy using peptide microarray immunoassay. J Allergy Clin Immunol (2012) 129(5):1321-8.e5. doi: 10.1016/j.jaci.2012.02.012
58. Bøgh KL, Nielsen H, Eiwegger T, Madsen CB, Mills ENC, Rigby NM, et al. IgE versus IgG4 epitopes of the peanut allergen Ara $\mathrm{h} 1$ in patients with severe allergy. Mol Immunol (2014) 58(2):169-76. doi: 10.1016/j.molimm. 2013.11.014

59. Dreskin SC, Germinaro M, Reinhold D, Chen X, Vickery BP, Kulis M, et al. IgE binding to linear epitopes of Ara $\mathrm{h} 2$ in peanut allergic preschool children undergoing oral Immunotherapy. Pediatr Allergy Immunol (2019) 30(8):817-23. doi: 10.1111/pai.13117

60. Mose AP, Mortz CG, Eller E, Sprogøe U, Barington T, Bindslev-Jensen C. Dose-time-response relationship in peanut allergy using a human model of passive cutaneous anaphylaxis. J Allergy Clin Immunol (2017) 139(6):20156.e4. doi: 10.1016/j.jaci.2016.11.034

61. Mose AP, Mortz E, Stahl Skov P, Mortz CG, Eller E, Sprogøe U, et al. The quest for ingested peanut protein in human serum. Allergy (2020) 75 (7):1721-9. doi: 10.1111/all.14109

62. Bernard H, Turner PJ, Ah-Leung S, Ruiz-Garcia M, Clare Mills EN, AdelPatient K. Circulating Ara h 6 as a marker of peanut protein absorption in tolerant and allergic humans following ingestion of peanut-containing foods. Clin Exp Allergy (2020) 50(9):1093-102. doi: 10.1111/cea.13706

63. JanssenDuijghuijsen LM, Wichers HJ, van Norren K, Keijer J, Baumert JL, de Jong GAH, et al. Detection of peanut allergen in human blood after consumption of peanuts is skewed by endogenous immunoglobulins. J Immunol Methods (2017) 440:52-7. doi: 10.1016/j.jim.2016.11.002

64. Moñino-Romero S, Lexmond WS, Singer J, Bannert C, Amoah AS, Yazdanbakhsh M, et al. Soluble FceRI: A biomarker for IgE-mediated diseases. Allergy (2019) 74(7):1381-4. doi: 10.1111/all.13734

65. Santos AF, Du Toit G, O’Rourke C, Becares N, Couto-Francisco N, Radulovic S, et al. Biomarkers of severity and threshold of allergic reactions during oral peanut challenges. J Allergy Clin Immunol (2020) 2:344-55. doi: 10.1016/j.jaci.2020.03.035

66. Chinthrajah RS, Purington N, Andorf S, Rosa JS, Mukai K, Hamilton R, et al. Development of a tool predicting severity of allergic reaction during peanut challenge. Ann Allergy Asthma Immunol (2018) 121(1):69-76.e2. doi: 10.1016/j.anai.2018.04.020

67. Santos AF, Barbosa-Morais NL, Hurlburt BK, Ramaswamy S, Hemmings O, Kwok M, et al. IgE to epitopes of Ara h 2 enhance the diagnostic accuracy of Ara h 2-specific IgE. Allergy (2020) 75(9):2309-18. doi: 10.1111/all.14301

68. Crestani E, Harb H, Charbonnier L-M, Leirer J, Motsinger-Reif A, Rachid R, et al. Untargeted metabolomic profiling identifies disease-specific signatures in food allergy and asthma. J Allergy Clin Immunol (2020) 145(3):897-906. doi: 10.1016/j.jaci.2019.10.014

69. Chiang D, Chen X, Jones SM, Wood RA, Sicherer SH, Burks AW, et al. Single-cell profiling of peanut-responsive $\mathrm{T}$ cells in patients with peanut allergy reveals heterogeneous effector $\mathrm{T}(\mathrm{H}) 2$ subsets. J Allergy Clin Immunol (2018) 141(6):2107-20. doi: 10.1016/j.jaci.2017.11.060

70. Ruiter B, Smith NP, Monian B, Tu AA, Fleming E, Virkud YV, et al. Expansion of the CD4(+) effector T-cell repertoire characterizes peanutallergic patients with heightened clinical sensitivity. J Allergy Clin Immunol (2020) 145(1):270-82. doi: 10.1016/j.jaci.2019.09.033

71. Tordesillas L, Rahman AH, Hartmann BM, Sampson HA, Berin MC. Mass cytometry profiling the response of basophils and the complete peripheral blood compartment to peanut. J Allergy Clin Immunol (2016) 138(6):17414.e9. doi: 10.1016/j.jaci.2016.06.048

72. Vadas P, Gold M, Perelman B, Liss GM, Lack G, Blyth T, et al. Plateletactivating factor, PAF acetylhydrolase, and severe anaphylaxis. $\mathrm{N} \mathrm{Engl} \mathrm{J} \mathrm{Med}$ (2008) 358(1):28-35. doi: 10.1056/NEJMoa070030

73. Arias K, Baig M, Colangelo M, Chu D, Walker T, Goncharova S, et al. Concurrent blockade of platelet-activating factor and histamine prevents life-threatening peanut-induced anaphylactic reactions. J Allergy Clin Immunol (2009) 124(2):307-14, 14.e1-2. doi: 10.1016/j.jaci.2009.03.012

74. Neeland MR, Andorf S, Manohar M, Dunham D, Lyu S-C, Dang TD, et al. Mass cytometry reveals cellular fingerprint associated with IgE+ peanut tolerance and allergy in early life. Nat Commun (2020) 11(1):1091. doi: 10.1038/s41467-020-14919-4

75. Tsai M, Mukai K, Chinthrajah RS, Nadeau KC, Galli SJ. Sustained successful peanut oral immunotherapy associated with low basophil activation and peanut-specific IgE. J Allergy Clin Immunol (2020) 145(3):885-96.e6. doi: $10.1016 /$ j.jaci.2019.10.038 
76. Rentzos G, Lundberg V, Lundqvist C, Rodrigues R, van Odijk J, Lundell AC, et al. Use of a basophil activation test as a complementary diagnostic tool in the diagnosis of severe peanut allergy in adults. Clin Transl Allergy (2015) 5:22. doi: 10.1186/s13601-015-0064-9

77. Santos AF, Douiri A, Bécares N, Wu SY, Stephens A, Radulovic S, et al. Basophil activation test discriminates between allergy and tolerance in peanut-sensitized children. J Allergy Clin Immunol (2014) 134(3):645-52. doi: 10.1016/j.jaci.2014.04.039

78. Reier-Nilsen T, Michelsen MM, Lødrup Carlsen KC, Carlsen KH, Mowinckel P, Nygaard UC, et al. Predicting reactivity threshold in children with anaphylaxis to peanut. Clin Exp Allergy (2018) 48(4):41523. doi: $10.1111 /$ cea. 13078

79. Santos AF, Du Toit G, Douiri A, Radulovic S, Stephens A, Turcanu V, et al. Distinct parameters of the basophil activation test reflect the severity and threshold of allergic reactions to peanut. J Allergy Clin Immunol (2015) 135 (1):179-86. doi: 10.1016/j.jaci.2014.09.001

80. Blom LH, Juel-Berg N, Larsen LF, Hansen KS, Poulsen LK. Circulating allergen-specific $\mathrm{T}(\mathrm{H}) 2$ lymphocytes: CCR4 $(+)$ rather than $\mathrm{CLA}(+)$ is the predominant phenotype in peanut-allergic subjects. J Allergy Clin Immunol (2018) 141(4):1498-501.e5. doi: 10.1016/j.jaci.2017.10.037

81. DeLong JH, Simpson KH, Wambre E, James EA, Robinson D, Kwok WW. Ara h 1-reactive $\mathrm{T}$ cells in individuals with peanut allergy. J Allergy Clin Immunol (2011) 127(5):1211-8.e3. doi: 10.1016/j.jaci.2011.02.028

82. Renand A, Farrington M, Whalen E, Wambre E, Bajzik V, Chinthrajah S, et al. Heterogeneity of Ara h Component-Specific CD4 T Cell Responses in Peanut-Allergic Subjects. Front Immunol (2018) 9:1408. doi: 10.3389/ fimmu.2018.01408

83. Weissler KA, Rasooly M, DiMaggio T, Bolan H, Cantave D, Martino D, et al. Identification and analysis of peanut-specific effector $\mathrm{T}$ and regulatory $\mathrm{T}$ cells in children allergic and tolerant to peanut. J Allergy Clin Immunol (2018) 141(5):1699-710.e7. doi: 10.1016/j.jaci.2018.01.035

84. Birrueta G, Tripple V, Pham J, Manohar M, James EA, Kwok WW, et al. Peanut-specific T cell responses in patients with different clinical reactivity. PloS One (2018) 13(10):e0204620. doi: 10.1371/journal.pone.0204620

85. Hong X, Hao K, Ladd-Acosta C, Hansen KD, Tsai HJ, Liu X, et al. Genomewide association study identifies peanut allergy-specific loci and evidence of epigenetic mediation in US children. Nat Commun (2015) 6:6304. doi: $10.1038 /$ ncomms 7304

86. Martino DJ, Ashley S, Koplin J, Ellis J, Saffery R, Dharmage SC, et al. Genomewide association study of peanut allergy reproduces association with amino acid polymorphisms in HLA-DRB1. Clin Exp Allergy (2017) 47 (2):217-23. doi: 10.1111/cea.12863

87. Asai Y, Eslami A, van Ginkel CD, Akhabir L, Wan M, Yin D, et al. A Canadian genome-wide association study and meta-analysis confirm HLA as a risk factor for peanut allergy independent of asthma. J Allergy Clin Immunol (2018) 141(4):1513-6. doi: 10.1016/j.jaci.2017.10.047

88. Asai Y, Eslami A, van Ginkel CD, Akhabir L, Wan M, Ellis G, et al. Genomewide association study and meta-analysis in multiple populations identifies new loci for peanut allergy and establishes C11orf30/EMSY as a genetic risk factor for food allergy. J Allergy Clin Immunol (2018) 141(3):991-1001. doi: 10.1016/j.jaci.2017.09.015

89. Watson CT, Cohain AT, Griffin RS, Chun Y, Grishin A, Hacyznska H, et al. Integrative transcriptomic analysis reveals key drivers of acute peanut allergic reactions. Nat Commun (2017) 8(1):1943. doi: 10.1038/s41467-017-02188-7

90. Do AN, Watson CT, Cohain AT, Griffin RS, Grishin A, Wood RA, et al. Dual transcriptomic and epigenomic study of reaction severity in peanut-allergic children. J Allergy Clin Immunol (2020) 145(4):1219-30. doi: 10.1016/ j.jaci.2019.10.040

91. Abdel-Gadir A, Stephen-Victor E, Gerber GK, Noval Rivas M, Wang S, Harb $\mathrm{H}$, et al. Microbiota therapy acts via a regulatory T cell MyD88/ROR $\gamma \mathrm{t}$ pathway to suppress food allergy. Nat Med (2019) 25(7):1164-74. doi: 10.1038/s41591-019-0461-z

92. Hua X, Goedert JJ, Pu A, Yu G, Shi J. Allergy associations with the adult fecal microbiota: Analysis of the American Gut Project. EBioMedicine (2015) 3:172-9. doi: 10.1016/j.ebiom.2015.11.038

93. He Z, Vadali VG, Szabady RL, Zhang W, Norman JM, Roberts B, et al. Increased diversity of gut microbiota during active oral immunotherapy in peanut-allergic adults. Allergy (2020). doi: 10.1111/all.14540
94. Hoh RA, Joshi SA, Lee J-Y, Martin BA, Varma S, Kwok S, et al. Origins and clonal convergence of gastrointestinal IgE+ B cells in human peanut allergy. Sci Immunol (2020) 5(45):eaay4209. doi: 10.1126/sciimmunol.aay4209

95. Petersen A, Kull S, Rennert S, Becker WM, Krause S, Ernst M, et al. Peanut defensins: Novel allergens isolated from lipophilic peanut extract. J Allergy Clin Immunol (2015) 136(5):1295-301.e1-5. doi: 10.1016/j.jaci.2015.04.010

96. de Jong GAH, Jayasena S, Johnson P, Marsh J, Apostolovic D, van Hage M, et al. Purification and Characterization of Naturally Occurring PostTranslationally Cleaved Ara h 6, an Allergen That Contributes Substantially to the Allergenic Potency of Peanut. J Agric Food Chem (2018) 66(41):10855-63. doi: 10.1021/acs.jafc.8b03140

97. Mamone G, Di Stasio L, De Caro S, Picariello G, Nicolai MA, Ferranti P. Comprehensive analysis of the peanut allergome combining 2-DE gel-based and gel-free proteomics. Food Res Int (2019) 116:1059-65. doi: 10.1016/ j.foodres.2018.09.045

98. Jappe U, Breiteneder H. Peanut allergy-Individual molecules as a key to precision medicine. Allergy (2019) 74(2):216-9. doi: 10.1111/all.13625

99. Beyer K, Grabenhenrich L, Härtl M, Beder A, Kalb B, Ziegert M, et al. Predictive values of component-specific IgE for the outcome of peanut and hazelnut food challenges in children. Allergy (2015) 70(1):90-8. doi: 10.1111/ all. 12530

100. Ebisawa M, Movérare R, Sato S, Borres M, Ito K. The predictive relationship between peanut- and Ara h 2-specific serum IgE concentrations and peanut allergy. J Allergy Clin Immunol In Pract (2015) 3:131-2.e1. doi: 10.1016/ j.jaip.2014.10.014

101. van Veen LN, Heron M, Batstra M, van Haard PMM, de Groot H. The diagnostic value of component-resolved diagnostics in peanut allergy in children attending a Regional Paediatric Allergology Clinic. BMC Pediatr (2016) 16:74-. doi: 10.1186/s12887-016-0609-7

102. Stasio L, Picariello G, Mongiello M, Nocerino R, Berni Canani R, Bavaro SL, et al. Peanut digestome: Identification of digestion resistant IgE binding peptides. Food Chem Toxicol (2017) 107:88-98. doi: 10.1016/j.fct. 2017.06.029

103. Prodic I, Stanic-Vucinic D, Apostolovic D, Mihailovic J, Radibratovic M, Radosavljevic J, et al. Influence of peanut matrix on stability of allergens in gastric-simulated digesta: $2 \mathrm{~S}$ albumins are main contributors to the $\operatorname{IgE}$ reactivity of short digestion-resistant peptides. Clin Exp Allergy (2018) 48 (6):731-40. doi: 10.1111/cea.13113

104. Dirks CG, Pedersen MH, Platzer MH, Bindslev-Jensen C, Skov PS, Poulsen LK. Does absorption across the buccal mucosa explain early onset of foodinduced allergic systemic reactions? J Allergy Clin Immunol (2005) 115 (6):1321-3. doi: 10.1016/j.jaci.2005.03.027

105. Schocker F, Baumert J, Kull S, Petersen A, Becker WM, Jappe U. Prospective investigation on the transfer of Ara h 2, the most potent peanut allergen, in human breast milk. Pediatr Allergy Immunol (2016) 27(4):348-55. doi: $10.1111 /$ pai.12533

106. Pekar J, Ret D, Untersmayr E. Stability of allergens. Mol Immunol (2018) 100:14-20. doi: 10.1016/j.molimm.2018.03.017

107. Turcanu V, Maleki SJ, Lack G. Characterization of lymphocyte responses to peanuts in normal children, peanut-allergic children, and allergic children who acquired tolerance to peanuts. J Clin Invest (2003) 111(7):1065-72. doi: $10.1172 /$ jcil6142

108. Noval Rivas M, Burton OT, Wise P, Charbonnier LM, Georgiev P, Oettgen $\mathrm{HC}$, et al. Regulatory $\mathrm{T}$ cell reprogramming toward a Th2-cell-like lineage impairs oral tolerance and promotes food allergy. Immunity (2015) 42 (3):512-23. doi: 10.1016/j.immuni.2015.02.004

109. Wisniewski JA, Commins SP, Agrawal R, Hulse KE, Yu MD, Cronin J, et al. Analysis of cytokine production by peanut-reactive $\mathrm{T}$ cells identifies residual Th2 effectors in highly allergic children who received peanut oral immunotherapy. Clin Exp Allergy (2015) 45(7):1201-13. doi: 10.1111/ cea. 12537

110. Glanville J, Huang H, Nau A, Hatton O, Wagar LE, Rubelt F, et al. Identifying specificity groups in the $\mathrm{T}$ cell receptor repertoire. Nature (2017) 547(7661):94-8. doi: 10.1038/nature22976

111. Smith NP, Ruiter B, Virkud YV, Shreffler WG. Identification of antigenspecific TCR sequences using a strategy based on biological and statistical enrichment in unselected subjects. bioRxiv (2020) 2020.05.11.088286. doi: $10.1101 / 2020.05 .11 .088286$ 
112. Brown SJ, Asai Y, Cordell HJ, Campbell LE, Zhao Y, Liao H, et al. Loss-offunction variants in the filaggrin gene are a significant risk factor for peanut allergy. J Allergy Clin Immunol (2011) 127(3):661-7. doi: 10.1016/ j.jaci.2011.01.031

113. Madore A-M, Vaillancourt VT, Asai Y, Alizadehfar R, Ben-Shoshan M, Michel DL, et al. HLA-DQB1 ${ }^{\star} 02$ and $\mathrm{DQB} 1^{\star} 06: 03 \mathrm{P}$ are associated with peanut allergy. Eur J Hum Genet (2013) 21(10):1181-4. doi: 10.1038/ejhg. 2013.13

114. Marenholz I, Grosche S, Kalb B, Rüschendorf F, Blümchen K, Schlags R, et al. Genome-wide association study identifies the SERPINB gene cluster as a susceptibility locus for food allergy. Nat Commun (2017) 8(1):1056-. doi: 10.1038/s41467-017-01220-0

115. Heintz-Buschart A, Wilmes P. Human Gut Microbiome: Function Matters. Trends Microbiol (2018) 26(7):563-74. doi: 10.1016/j.tim.2017.11.002

116. Jiménez-Saiz R, Anipindi VC, Galipeau H, Ellenbogen Y, Chaudhary R, Koenig JF, et al. Microbial Regulation of Enteric Eosinophils and Its Impact on Tissue Remodeling and Th2 Immunity. Front Immunol (2020) 11:155 (155). doi: 10.3389/fimmu.2020.00155

117. Petersen J, Ciacchi L, Tran MT, Loh KL, Kooy-Winkelaar Y, Croft NP, et al. $\mathrm{T}$ cell receptor cross-reactivity between gliadin and bacterial peptides in celiac disease. Nat Struct Mol Biol (2020) 27(1):49-61. doi: 10.1038/s41594019-0353-4

118. Bresciani A, Paul S, Schommer N, Dillon MB, Bancroft T, Greenbaum J, et al. $\mathrm{T}$-cell recognition is shaped by epitope sequence conservation in the host proteome and microbiome. Immunology (2016) 148(1):34-9. doi: 10.1111/ imm. 12585

119. Carrasco Pro S, Lindestam Arlehamn CS, Dhanda SK, Carpenter C, Lindvall M, Faruqi AA, et al. Microbiota epitope similarity either dampens or enhances the immunogenicity of disease-associated antigenic epitopes. PLoS One (2018) 13(5):e0196551. doi: 10.1371/journal.pone.0196551

120. Honda K, Littman DR. The microbiota in adaptive immune homeostasis and disease. Nature (2016) 535(7610):75-84. doi: 10.1038/nature18848

121. Wong KJ, Timbrell V, Xi Y, Upham JW, Collins AM, Davies JM. IgE+ B cells are scarce, but allergen-specific B cells with a memory phenotype circulate in patients with allergic rhinitis. Allergy (2015) 70(4):420-8. doi: 10.1111/ all. 12563

122. Saunders SP, Ma EGM, Aranda CJ, Curotto de Lafaille MA. Non-classical B Cell Memory of Allergic IgE Responses. Front Immunol (2019) 10:715(715). doi: 10.3389/fimmu.2019.00715

123. Kolmannskog S, Haneberg B. Immunoglobulin $\mathrm{E}$ in feces from children with allergy. Evidence of local production of IgE in the gut. Int Arch Allergy Appl Immunol (1985) 76(2):133-7. doi: 10.1159/000233679

124. Segal JP, Mullish BH, Quraishi MN, Acharjee A, Williams HRT, Iqbal T, et al. The application of omics techniques to understand the role of the gut microbiota in inflammatory bowel disease. Therap Adv Gastroenterol (2019) 12:1756284818822250. doi: 10.1177/1756284818822250

125. Li L, Figeys D. Proteomics and Metaproteomics Add Functional, Taxonomic and Biomass Dimensions to Modeling the Ecosystem at the MucosalLuminal Interface. Mol Cell Proteomics (2020) 19(9):1409-17. doi: $10.1074 / \mathrm{mcp} . \mathrm{R} 120.002051$

126. Arasi S, Mennini M, Valluzzi R, Riccardi C, Fiocchi A. Precision medicine in food allergy. Curr Opin Allergy Clin Immunol (2018) 18(5):438-43. doi: 10.1097/aci.0000000000000465

127. Delhalle S, Bode SFN, Balling R, Ollert M, He FQ. A roadmap towards personalized immunology. NPJ Syst Biol Appl (2018) 4(1):9. doi: 10.1038/ s41540-017-0045-9

128. Donovan BM, Bastarache L, Turi KN, Zutter MM, Hartert TV. The current state of omics technologies in the clinical management of asthma and allergic diseases. Ann Allergy Asthma Immunol (2019) 123(6):550-7. doi: 10.1016/ j.anai.2019.08.460

129. Dhondalay GK, Rael E, Acharya S, Zhang W, Sampath V, Galli SJ, et al. Food allergy and omics. J Allergy Clin Immunol (2018) 141(1):20-9. doi: 10.1016/ j.jaci.2017.11.007

130. Krogulska A, Wood RA. Peanut allergy diagnosis: Moving from basic to more elegant testing. Pediatr Allergy Immunol (2020) 31(4):346-57. doi: $10.1111 /$ pai.13215

131. Vickery BP, Vereda A, Casale TB, Beyer K, du Toit G, Hourihane JO, et al. AR101 Oral Immunotherapy for Peanut Allergy. N Engl J Med (2018) 379 (21):1991-2001. doi: 10.1056/NEJMoa1812856

132. Du Toit G, Roberts G, Sayre PH, Bahnson HT, Radulovic S, Santos AF, et al. Randomized trial of peanut consumption in infants at risk for peanut allergy. N Engl J Med (2015) 372(9):803-13. doi: 10.1056/NEJMoa1414850

Conflict of Interest: PS declares being a scientific advisor in RefLab ApS. CB-J declares being a Clinical Investigator for Novartis, Aimmune, Hal Allergy, Allakos, and Miltenyi.

The remaining authors declare that the research was conducted in the absence of any commercial or financial relationships that could be construed as a potential conflict of interest.

Copyright (C) 2021 Czolk, Klueber, Sørensen, Wilmes, Codreanu-Morel, Skov, Hilger, Bindslev-Jensen, Ollert and Kuehn. This is an open-access article distributed under the terms of the Creative Commons Attribution License (CC BY). The use, distribution or reproduction in other forums is permitted, provided the original author(s) and the copyright owner(s) are credited and that the original publication in this journal is cited, in accordance with accepted academic practice. No use, distribution or reproduction is permitted which does not comply with these terms. 